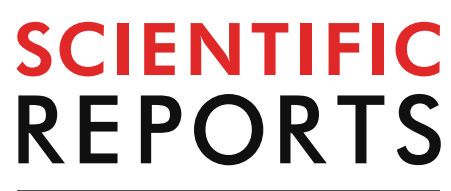

natureresearch

Check for updates

\title{
Hydrochemical composition and potentially toxic elements in the Kyrgyzstan portion of the transboundary Chu-Talas river basin, Central Asia
}

Long $\mathrm{Ma}^{1,2,3 凶}$, Yaoming $\mathrm{Li}^{1,2,3}$, Jilili Abuduwaili ${ }^{1,2,3}$, Salamat Abdyzhapar uulu ${ }^{2,4}$ \& Wen $\mathrm{Liu}^{1,2,3}$

Water chemistry and the assessment of health risks of potentially toxic elements have important research significance for water resource utilization and human health. However, not enough attention has been paid to the study of surface water environments in many parts of Central Asia. Sixty water samples were collected from the transboundary river basin of Chu-Talas during periods of high and low river flow, and the hydrochemical composition, including major ions and potentially toxic elements $(\mathrm{Zn}, \mathrm{Pb}, \mathrm{Cu}, \mathrm{Cr}$, and $\mathrm{As}$ ), was used to determine the status of irrigation suitability and risks to human health. The results suggest that major ions in river water throughout the entire basin are mainly affected by water-rock interactions, resulting in the dissolution and weathering of carbonate and silicate rocks. The concentrations of major ions change to some extent with different hydrological periods; however, the hydrochemical type of calcium carbonate remains unchanged. Based on the water-quality assessment, river water in the basin is classified as excellent/good for irrigation. The relationship between potentially toxic elements $(\mathrm{Zn}, \mathrm{Pb}, \mathrm{Cu}, \mathrm{Cr}$, and $\mathrm{As}$ ) and major ions is basically the same between periods of high and low river flow. There are significant differences between the sources of potentially toxic elements $(\mathrm{Zn}, \mathrm{Pb}, \mathrm{Cu}$, and $\mathrm{As})$ and major ions; however, $\mathrm{Cr}$ may share the same rock source as major ions. The risk assessment revealed low non-carcinogenic and carcinogenic risks for human health; however, the maximum carcinogenic risk for As exceeded the allowable value, which requires further consideration. These results provide a scientific basis for the management of agricultural irrigation uses and also infill existing gaps regarding the hydrochemical composition in the Chu-Talas river basin, Central Asia.

Water is important for the movement and transformation of material in nature, and water resources are important for the sustenance of life and social and economic development. Central Asia, located in the hinterland of Eurasia, has a semi-arid and arid continental climate, with scarce precipitation and extensive evaporation ${ }^{1}$. The shortage of water resources has seriously restricted the development of Central Asia ${ }^{2,3}$. To date, most studies on water resources in Central Asia have focused on the quantity of water under the influence of recent climatic and anthropogenic factors ${ }^{4-7}$. In particular, in view of the Aral Sea disaster ${ }^{8}$, systematic studies have been carried out on the quantity and management of water in the Syr Darya and Amu Darya rivers and reasons for changing water resources ${ }^{9-12}$. However, with the over-development of water resources and other human activities, a shortage in water resources has resulted, and at the same time, water resources in Central Asia have become seriously polluted ${ }^{13}$. Increased concentrations of toxic elements have been found in humans in the Aral Sea basin ${ }^{14}$. Nuclear tailing dumps ${ }^{15}$ and gold mining ${ }^{16}$ had important impacts on the water environment of Kyrgyzstan.

${ }^{1}$ State Key Laboratory of Desert and Oasis Ecology, Xinjiang Institute of Ecology and Geography, Chinese Academy of Sciences, Urumqi 830011, China. ${ }^{2}$ Research Center for Ecology and Environment of Central Asia, Chinese Academy of Sciences, Urumqi 830011, China. ${ }^{3}$ University of Chinese Academy of Sciences, Beijing 100049, China. ${ }^{4}$ Institute of Geology, National Academy of Sciences of Kyrgyzstan, 720461 Bishkek, Kyrgyzstan. ${ }^{\square}$ email: malong@ms.xjb.ac.cn 
Quality has a direct impact on the safe use of water for industrial, agricultural and drinking purposes. Among research studies examining water resources, relatively few are concerned with water quality. At present, most such studies are focused on water quality in the Syr Darya River of the Aral Sea Basin, especially with respect to radioactive pollution ${ }^{17,18}$. However, not enough attention has been paid to the study of surface water environments in other parts of Central Asia.

The Chu and Talas rivers originate in the Tianshan Mountains and dissipate in the Muyunkum Desert. Precipitation mainly occurs from October to April ${ }^{19}$. The main source of flowing water is from the melting of snowfields and glaciers ${ }^{19}$. In the Talas River and Chu River sub-basins, bedrocks are mainly composed of acid plutonic rocks, siliciclastic sedimentary rocks, carbonate sedimentary rocks, mixed sedimentary rocks, and Quaternary unconsolidated sediments ${ }^{20}$. Based on information from the Harmonized World Soil Database (v 1.2) $)^{21}$, soils in the Talas River sub-basin are composed of leptosol and Calcisols, and soils in the study area of the Chu River are composed of leptosol, Calcisols, and Kastanozem ${ }^{21}$. The sub-basin of the Chu River covers an area of $71,600 \mathrm{~km}^{2}$, and the river has a maximum length of $1,067 \mathrm{~km}^{22}$. The sub-basin of the Talas River covers an area of $52,700 \mathrm{~km}^{2}$, and the river has a maximum length of $661 \mathrm{~km}^{22}$. The importance of studying the Chu and Talas rivers lies in the fact that these two rivers are international rivers flowing through the territories of Kyrgyzstan and Kazakhstan and changes of water quality and quantity in the upstream countries have important impacts on the lower reaches. Transboundary water conflicts in Central Asia have become a very serious problem in the world ${ }^{23-25}$. In addition, the water resources of the Chu River and Talas River are mainly used for agricultural irrigation $^{22}$, and changes in water quality have a significant impact on the safe use of water in agriculture. In addition, the pollution of potentially toxic elements in water is a hot issue in current researches ${ }^{26,27}$. The increased content of $\mathrm{Cu}$ and As can lead to certain inflammatory diseases and cardiac dysfunction ${ }^{28}$, and As has significant carcinogenicity ${ }^{29}$. Moderate or high zinc intake may be associated with the risk of prostate cancer ${ }^{30}$. Chronic toxicity of $\mathrm{Pb}$ is manifested as liver toxicity, nephrotoxicity and neurotoxicity, which can cause growth delay, neuronal defects and anemia in children ${ }^{31,32}$. Cr has been shown to be related to certain diseases such as nasal septum defect, liver and kidney damage, dermatitis, internal haemorrhage, and respiratory ${ }^{33,34}$.

Based on the above considerations, 60 water samples were collected from the transboundary Chu-Talas river basin during low river flow $(\mathrm{n}=30)$ in May and high river flow $(\mathrm{n}=30)$ in July and August, and the river waters were analyzed for hydrochemical composition and potentially toxic elements ( $\mathrm{Pb}, \mathrm{Zn}, \mathrm{Cu}, \mathrm{Cr}$, and $\mathrm{As}$ ). The study of water quality in this region can provide a scientific basis for the management of water for agricultural irrigation uses, as well as infill existing gaps regarding the hydrochemical composition of Chu and Talas river water. In addition, an important supplement to the study is the role of human activities in reforming the surface water chemical composition of Central Asia.

\section{Results}

During the period of low river flow, the $\mathrm{pH}$ value ranged from 7.33 to 8.84 , with an average value of 8.24. Conductivity ranged between 65.0 and $521.90 \mu \mathrm{S} \mathrm{cm}^{-1}$, with an average value of $213.22 \mu \mathrm{S} \mathrm{cm}^{-1}$. TDS varied between 80.21 and $474.79 \mathrm{mg} \mathrm{L}^{-1}$, with an average value of $229.74 \mathrm{mg} \mathrm{L}^{-1}$ (Table 1).

During the period of low river flow, the $\mathrm{Ca}^{2+}$ varied from 10.27 to $63.75 \mathrm{mg} \mathrm{L}^{-1}$ with a mean value of $29.41 \mathrm{mg}$ $\mathrm{L}^{-1}$, and the $\mathrm{Mg}^{2+}$ had a range of 1.10 to $22.42 \mathrm{mg} \mathrm{L}^{-1}$ with a mean value of $7.05 \mathrm{mg} \mathrm{L}^{-1}$. The minimum, mean, and maximum values for $\mathrm{Na}^{+}$were $0.40,4.25$, and $15.43 \mathrm{mg} \mathrm{L}^{-1}$, respectively. The $\mathrm{K}^{+}$values varied from 0.62 to $2.24 \mathrm{mg} \mathrm{L}^{-1}$, with an average value of $1.34 \mathrm{mg} \mathrm{L}^{-1}$. The $\mathrm{HCO}_{3}{ }^{-}$varied from 43.97 to $311.40 \mathrm{mg} \mathrm{L}^{-1}$ with a mean value of $156.31 \mathrm{mg} \mathrm{L}^{-1}$, and $\mathrm{SO}_{4}{ }^{2-}$ had a range of 4.77 to $79.38 \mathrm{mg} \mathrm{L}^{-1}$ with a mean value of $24.95 \mathrm{mg} \mathrm{L}^{-1}$. The minimum, mean, and maximum values for $\mathrm{Cl}^{-}$were $0.48,12.77$, and $2.25 \mathrm{mg} \mathrm{L}^{-1}$, respectively. The $\mathrm{NO}_{3}{ }^{-}$values varied from 2.19 to $6.92 \mathrm{mg} \mathrm{L}^{-1}$, with an average value of $3.73 \mathrm{mg} \mathrm{L}^{-1}$.

With respect to potentially toxic elements during low river flow, the concentration of $\mathrm{Zn}$ ranged from 1.104 to $9.855 \mu \mathrm{g} \mathrm{L} \mathrm{L}^{-1}$, with an average value of $4.972 \mu \mathrm{g} \mathrm{L} \mathrm{L}^{-1}$; $\mathrm{Pb}$ ranged between 0.046 and $2.976 \mu \mathrm{g} \mathrm{L}^{-1}$, with an average of $0.929 \mu \mathrm{g} \mathrm{L}^{-1}$; and, Cu varied between 0.376 and $9.570 \mu \mathrm{g} \mathrm{L}^{-1}$, with an average value of $2.298 \mu \mathrm{g} \mathrm{L}^{-1}$; The minimum, mean, and maximum values for $\mathrm{Cr}$ were $0.20,0.034$, and $0.060 \mathrm{mg} \mathrm{L}^{-1}$, respectively. The As concentration varied from 0.323 to $3.417 \mu \mathrm{g} \mathrm{L}{ }^{-1}$, with an average value of $1.335 \mu \mathrm{g} \mathrm{L}^{-1}$.

During the period of high river flow, the $\mathrm{pH}$ value ranged from 7.14 to 8.99 , with an average value of 8.58. Conductivity values ranged between $36-542 \mu \mathrm{S} \mathrm{cm}^{-1}$, with an average value of $195.93 \mu \mathrm{S} \mathrm{cm} \mathrm{cm}^{-1}$. TDS varied between 76.11 and $414.84 \mathrm{mg} \mathrm{L}^{-1}$, with an average value of $205.76 \mathrm{mg} \mathrm{L}^{-1}$.

For major ions, $\mathrm{Ca}^{2+}$ varied from 9.66 to $59.65 \mathrm{mg} \mathrm{L}^{-1}$ with a mean value of $26.66 \mathrm{mg} \mathrm{L}^{-1}$, and $\mathrm{Mg}^{2+}$ had a range of 0.75 to $24.64 \mathrm{mg} \mathrm{L}^{-1}$ with a mean value of $6.30 \mathrm{mg} \mathrm{L}^{-1}$. The minimum, mean, and maximum values for $\mathrm{Na}^{+}$were $0.37,3.27$, and $15.46 \mathrm{mg} \mathrm{L}^{-1}$, respectively. The $\mathrm{K}^{+}$values varied from 0.54 to $2.35 \mathrm{mg} \mathrm{L}^{-1}$, with an average value of $1.15 \mathrm{mg} \mathrm{L}^{-1}$. The $\mathrm{HCO}_{3}{ }^{-}$concentration varied from 56.75 to $284.28 \mathrm{mg} \mathrm{L}^{-1}$ with a mean value of $143.58 \mathrm{mg} \mathrm{L}^{-1}$, and $\mathrm{SO}_{4}^{2-}$ had a range of 4.02 to $41.80 \mathrm{mg} \mathrm{L}^{-1}$ with a mean value of $19.81 \mathrm{mg} \mathrm{L}^{-1}$. The minimum, mean, and maximum values for $\mathrm{Cl}^{-}$were $0.25,1.8$, and $12.61 \mathrm{mg} \mathrm{L}^{-1}$, respectively. The $\mathrm{NO}_{3}{ }^{-}$values varied from 1.17 to $6.12 \mathrm{mg} \mathrm{L}^{-1}$, with an average value of $2.84 \mathrm{mg} \mathrm{L}^{-1}$.

With respect to potentially toxic elements, the $\mathrm{Zn}$ concentration ranged from 0.95 to $22.664 \mu \mathrm{g} \mathrm{L}^{-1}$, with an average value of $5.047 \mu \mathrm{g} \mathrm{L}^{-1}$. The range in $\mathrm{Pb}$ concentrations was from 0.054 to $4.655 \mu \mathrm{g} \mathrm{L}{ }^{-1}$, with an average of $1.096 \mu \mathrm{g} \mathrm{L}{ }^{-1}$, while $\mathrm{Cu}$ varied between $0.154-11.853 \mu \mathrm{g} \mathrm{L}^{-1}$ with an average value of $2.210 \mu \mathrm{g} \mathrm{L}^{-1}$. The minimum, mean, and maximum values for $\mathrm{Cr}$ were $0.020,0.037$ and $0.080 \mathrm{mg} \mathrm{L}^{-1}$, respectively. The As concentrations ranged from 0.271 to $3.316 \mu \mathrm{g} \mathrm{L} \mathrm{L}^{-1}$, with an average value of $1.258 \mu \mathrm{g} \mathrm{L}^{-1}$.

According to independent sample tests of different water chemistry parameters at the two periods (Table S1 in supplementary information, there were some significant differences for $\mathrm{NO}_{3}{ }^{-}(\mathrm{t}=-2.958, p=0.004<0.05)$ and $\mathrm{Cd}(\mathrm{t}=-2.377, p=0.026<0.05)$ at the two periods. For other hydrochemical parameters for the same sampling point at different periods, there were no statistically significant differences. 


\begin{tabular}{|c|c|c|c|c|c|c|c|}
\hline Indicators & Period & Minimum & Maximum & Mean & Median & SD & SE \\
\hline \multirow{2}{*}{$\mathrm{Ca}\left(\mathrm{mg} \mathrm{L}^{-1}\right)$} & $\mathrm{L}$ & 10.27 & 63.75 & 29.41 & 24.16 & 12.93 & 2.36 \\
\hline & $\mathrm{H}$ & 9.66 & 59.65 & 26.66 & 22.36 & 12.33 & 2.25 \\
\hline \multirow{2}{*}{$\operatorname{Mg}\left(\mathrm{mg} \mathrm{L}^{-1}\right)$} & $\mathrm{L}$ & 1.10 & 22.42 & 7.05 & 5.15 & 5.28 & 0.96 \\
\hline & $\mathrm{H}$ & 0.75 & 24.64 & 6.30 & 4.23 & 5.15 & 0.94 \\
\hline \multirow{2}{*}{$\mathrm{K}\left(\mathrm{mg} \mathrm{L}^{-1}\right)$} & $\mathrm{L}$ & 0.62 & 2.24 & 1.34 & 1.23 & 0.46 & 0.08 \\
\hline & $\mathrm{H}$ & 0.54 & 2.35 & 1.15 & 1.06 & 0.45 & 0.08 \\
\hline \multirow{2}{*}{$\mathrm{Na}\left(\mathrm{mg} \mathrm{L}^{-1}\right)$} & $\mathrm{L}$ & 0.40 & 15.43 & 4.25 & 2.78 & 3.98 & 0.73 \\
\hline & $\mathrm{H}$ & 0.37 & 15.46 & 3.27 & 1.66 & 3.90 & 0.71 \\
\hline \multirow{2}{*}{$\mathrm{HCO}_{3}\left(\mathrm{mg} \mathrm{L}^{-1}\right)$} & $\mathrm{L}$ & 43.97 & 311.40 & 156.31 & 140.19 & 66.75 & 12.19 \\
\hline & $\mathrm{H}$ & 56.75 & 284.28 & 143.58 & 128.09 & 65.27 & 11.92 \\
\hline \multirow{2}{*}{$\mathrm{SO}_{4}\left(\mathrm{mg} \mathrm{L}^{-1}\right)$} & $\mathrm{L}$ & 4.77 & 79.38 & 24.95 & 22.22 & 17.10 & 3.12 \\
\hline & $\mathrm{H}$ & 4.02 & 41.80 & 19.81 & 16.90 & 11.49 & 2.10 \\
\hline \multirow{2}{*}{$\mathrm{Cl}\left(\mathrm{mg} \mathrm{L}^{-1}\right)$} & $\mathrm{L}$ & 0.48 & 12.77 & 2.25 & 1.37 & 2.61 & 0.48 \\
\hline & $\mathrm{H}$ & 0.25 & 12.61 & 1.80 & 0.75 & 2.73 & 0.50 \\
\hline \multirow{2}{*}{$\mathrm{NO}_{3}\left(\mathrm{mg} \mathrm{L}^{-1}\right)$} & $\mathrm{L}$ & 2.19 & 6.92 & 3.73 & 3.57 & 1.22 & 0.22 \\
\hline & $\mathrm{H}$ & 1.17 & 6.12 & 2.84 & 2.68 & 1.10 & 0.20 \\
\hline \multirow{2}{*}{$\mathrm{pH}$} & $\mathrm{L}$ & 7.33 & 8.84 & 8.24 & 8.47 & 0.55 & 0.10 \\
\hline & $\mathrm{H}$ & 7.14 & 8.99 & 8.58 & 8.73 & 0.42 & 0.08 \\
\hline \multirow{2}{*}{$\mathrm{EC}\left(\mu \mathrm{S} \mathrm{cm}^{-1}\right)$} & $\mathrm{L}$ & 65.00 & 521.90 & 213.22 & 193.30 & 102.23 & 18.66 \\
\hline & $\mathrm{H}$ & 36.00 & 542.00 & 195.93 & $\mid 145.15$ & 132.92 & 24.27 \\
\hline \multirow{2}{*}{$\operatorname{TDS}\left(\mathrm{mg} \mathrm{L}^{-1}\right)$} & $\mathrm{L}$ & 80.21 & \begin{tabular}{|l|}
474.79 \\
\end{tabular} & 229.74 & 194.72 & 100.59 & \begin{tabular}{|l|}
18.37 \\
\end{tabular} \\
\hline & $\mathrm{H}$ & 76.11 & 414.84 & 205.76 & 171.61 & 94.10 & 17.18 \\
\hline \multirow{2}{*}{$\mathrm{Pb}\left(\mu \mathrm{g} \mathrm{L}^{-1}\right)$} & $\mathrm{L}$ & 0.046 & 2.976 & 0.929 & 0.710 & 0.782 & 0.143 \\
\hline & $\mathrm{H}$ & 0.054 & 4.655 & 1.096 & 0.665 & 1.175 & 0.215 \\
\hline \multirow{2}{*}{$\mathrm{Zn}\left(\mu \mathrm{g} \mathrm{L} \mathrm{L}^{-1}\right)$} & $\mathrm{L}$ & 1.104 & 9.855 & 4.972 & 5.097 & 2.250 & 0.411 \\
\hline & $\mathrm{H}$ & 0.950 & 22.664 & 5.047 & 3.106 & 5.150 & 0.940 \\
\hline \multirow{2}{*}{$\mathrm{Cu}\left(\mu \mathrm{g} \mathrm{L}^{-1}\right)$} & $\mathrm{L}$ & 0.376 & 9.570 & 2.298 & 1.792 & 2.217 & 0.405 \\
\hline & $\mathrm{H}$ & 0.154 & 11.853 & 2.210 & 1.023 & 3.113 & 0.568 \\
\hline \multirow{2}{*}{$\mathrm{Cr}\left(\mathrm{mg} \mathrm{L}^{-1}\right)$} & $\mathrm{L}$ & 0.020 & 0.060 & 0.034 & 0.030 & 0.009 & 0.002 \\
\hline & $\mathrm{H}$ & 0.020 & 0.080 & 0.037 & 0.040 & 0.012 & 0.002 \\
\hline \multirow{2}{*}{ As $\left(\mu \mathrm{g} \mathrm{L}^{-1}\right)$} & $\mathrm{L}$ & 0.323 & 3.417 & 1.335 & 0.878 & 1.020 & 0.186 \\
\hline & $\mathrm{H}$ & 0.271 & 3.316 & 1.258 & 0.904 & 0.996 & 0.182 \\
\hline
\end{tabular}

Table 1. Statistical summary of environmental indicators of river water quality in the Chu-Talas Basin during periods of low river flow $(L, n=30)$ and high river flow $(H, n=30)$.

\section{Discussion}

Factors influencing the chemical composition of river waters in the Chu-Talas Basin. Cluster analysis ${ }^{35-39}$ was used to reveal the differences between potentially toxic elements and major ions, and differences among water samples from the Chu-Talas Basin. The method of Euclidean distance was used in the cluster analysis for the similarity measure, and the method of Ward's minimum variance was used for the clustering of variables and row dendrograms. The results are represented as heat maps in Figs. 1 and 2 for low and high flow periods, respectively. The top dendrogram shows the similarity between major ions and potentially toxic elements, while the left dendrogram shows clustering of the river water samples (the samples are shown in Table S1).

As noted from the top dendrogram in both Figs. 1 and 2, Cr was strongly linked with major ions indicating a strong influence from water rock interactions. The relationship between potentially toxic elements and major ions was generally the same during periods of low and high river flow. However, an obvious linkage with $\mathrm{Zn}, \mathrm{Pb}$, $\mathrm{Cu}$, and As was also observed during the low flow period. Furthermore, human activities may have influenced the potentially toxic elements $\mathrm{Zn}, \mathrm{Pb}, \mathrm{Cu}$, and $\mathrm{As}$. The left dendrogram provided detailed information about the water samples from which spatial differences were inferred. No spatial accumulation of sampling locations was observed during either the dry season or the rainy season. It can thus be concluded that the cluster analysis of major ions and potentially toxic elements indicates no significant differences between the two sub-basins; however, differences were observed in the relationship between the major ions reflecting differences between the different hydrological periods. Whether this significantly impacts the hydrochemistry is discussed through the following analysis.

Piper diagrams are widely used to display dominant hydrochemical ions, and are useful for revealing the source of the hydrochemical composition ${ }^{40-42}$. All of the water samples were of the calcium bicarbonate type $\left(\mathrm{Ca}-\mathrm{HCO}_{3}\right)$ (Fig. 3), which suggests that there is no difference in the classification of water chemistry between water samples collected from the Chu-Talas river basin during low flow and high flow periods. However, the 


\section{Clustered Heat Map}

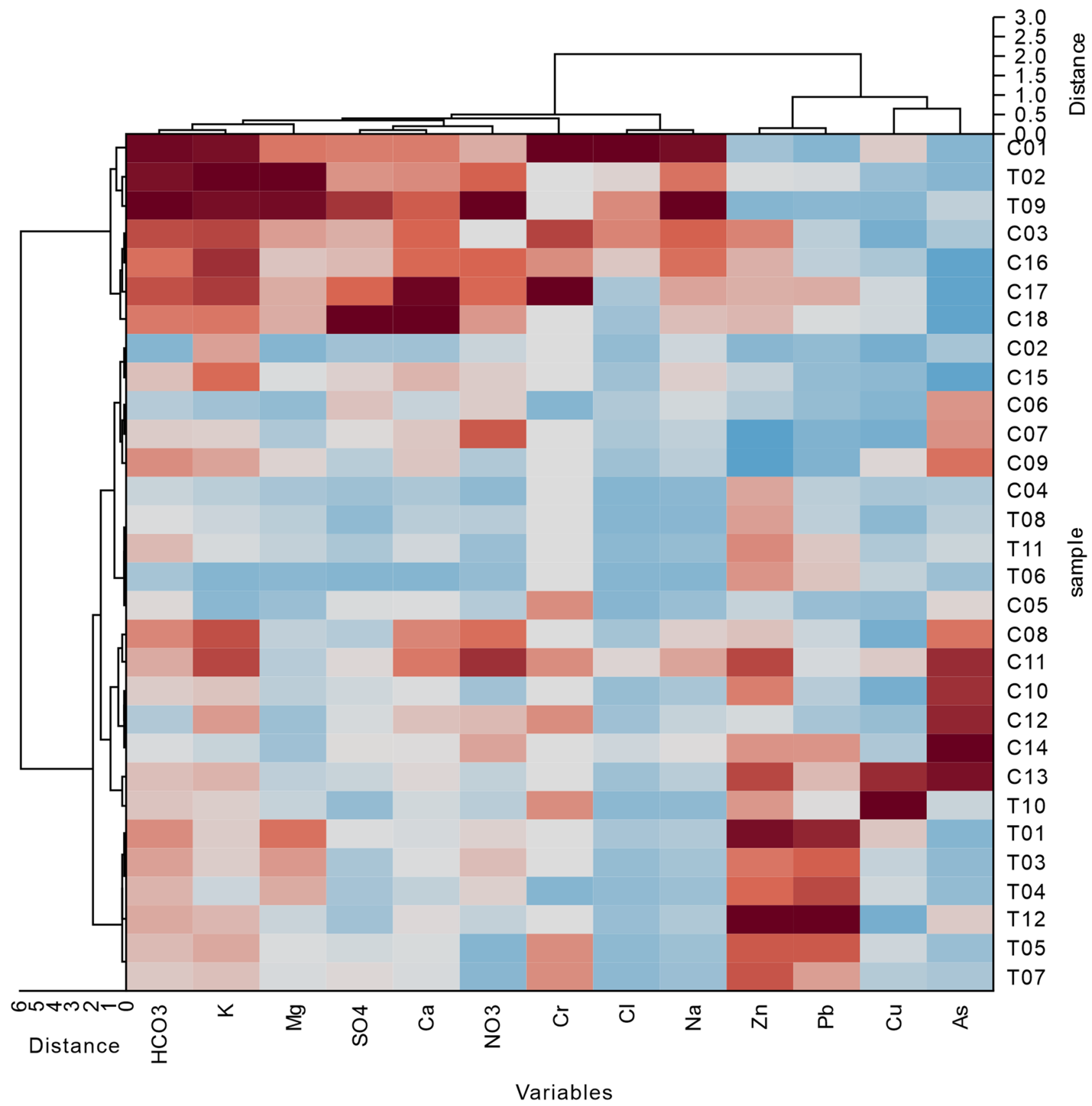

$\min$

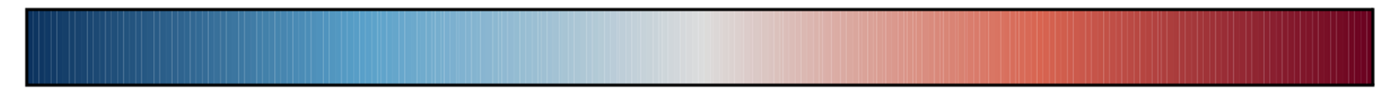

$\max$

\section{Data Value}

Figure 1. A heat map of the two-dimensional hierarchical cluster analysis suggesting differential clustering of the influencing factors on potentially toxic elements in river waters during the period of low river flow. 


\section{Clustered Heat Map}

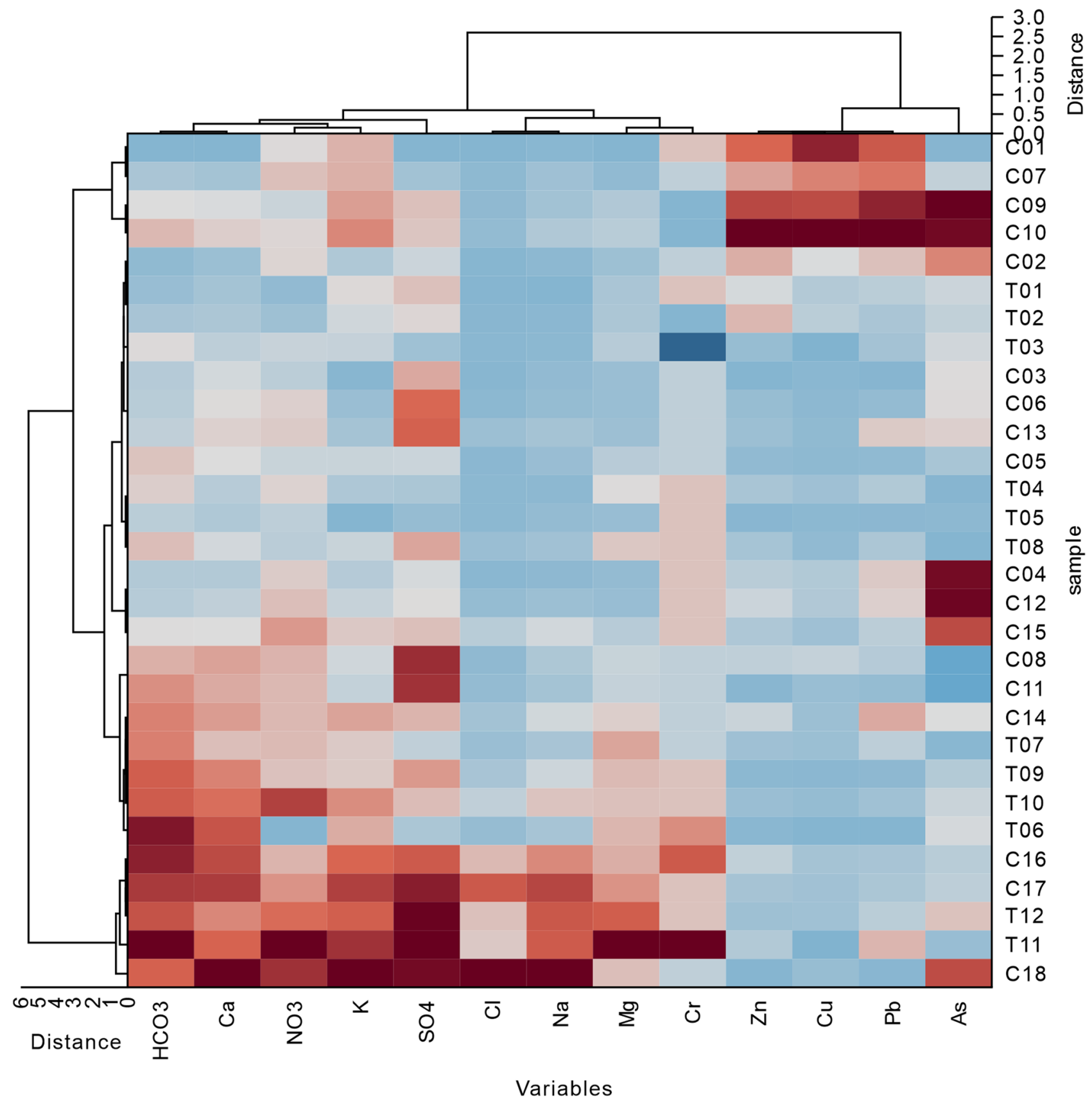

$\min$

\section{Data Value}

Figure 2. A heat map of the two-dimensional hierarchical cluster analysis suggesting differential clustering of the influencing factors on potentially toxic elements in river waters during the period of high river flow. 

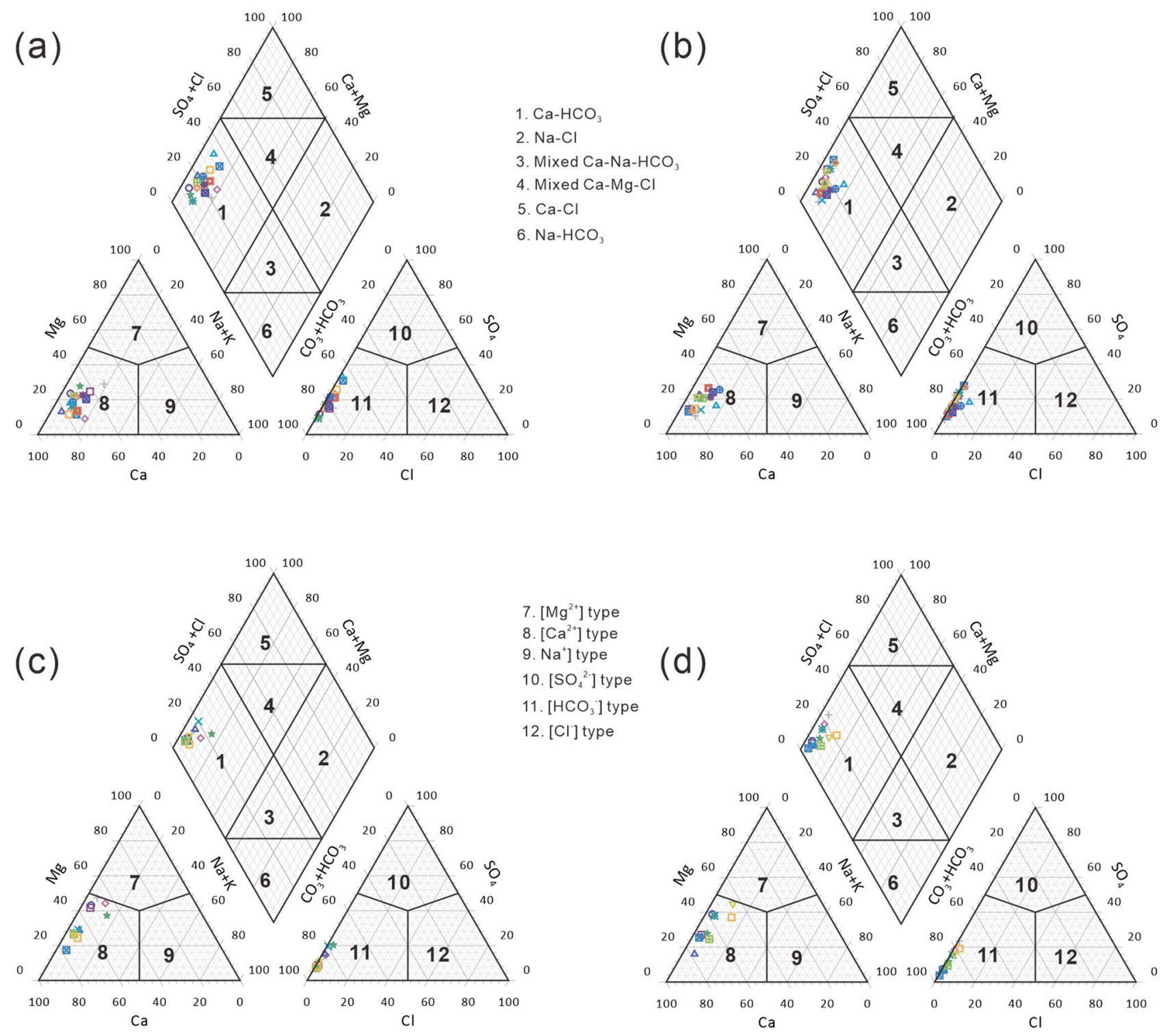

Figure 3. Piper diagrams for water samples from the Chu-Talas river basin. (A) Chu River system during low river flow; (B) Chu River system during high river flow; (C) Talas River system during low river flow; (D) Talas River system during high river flow.

relative content of $\mathrm{Mg}^{2+}$ ions in the Talas River sub-basin was higher than that in the Chu River sub-basin, as seen from Fig. 3. On the Gibbs diagrams presented in Fig. 4, the river water samples mostly plotted within the area of rock dominance located between the two end-members of Carbonate and Silicate, which suggests that major ions have mainly been influenced by the process of water-rock interactions. This reflects the fact that the two rivers are adjacent to each other sharing the same geological background and source rocks under the same climatic conditions ${ }^{43}$. This leads to insignificant differences in major ions between the two sub-basins.

Based on the simulation for distribution of species and calculation of Saturation indices (see the Supplementary Information for simulation results), the results are basically consistent with the above-mentioned discussion. Saturation indices for Aragonite, Calcite, $\mathrm{Cr}(\mathrm{OH})_{3}$, Dolomite (disordered), and Dolomite (ordered) fluctuated around 0 (Fig. 5). The phases $\mathrm{Cr}(\mathrm{OH})_{3}(\mathrm{am})$ and $\mathrm{Cr}_{2} \mathrm{O}_{3}$ are in a supersaturated state. The Saturation indices of the remaining mineral phases are far less than zero. The bedrock of the Lake watershed contains a lot of carbonates and evaporative salts, and the saturation index of surface water bodies of Aragonite and Calcite is nearly saturated ${ }^{44}$. The Saturation indices in the low-flow period are smaller than that in the high-flow period, reflecting the enhancement of watershed weathering and water-rock interaction during the latter period.

Human health risk assessment and water irrigation evaluation. Wilcox diagrams are widely used to assess water suitable for irrigation ${ }^{45-49}$. In the Wilcox diagram shown in Fig. 6 , the sodium percentage $(\% \mathrm{Na})$ versus EC was plotted to assess water quality for irrigation, which shows that river water in the Chu-Talas Basin is excellent/good for irrigation use. 

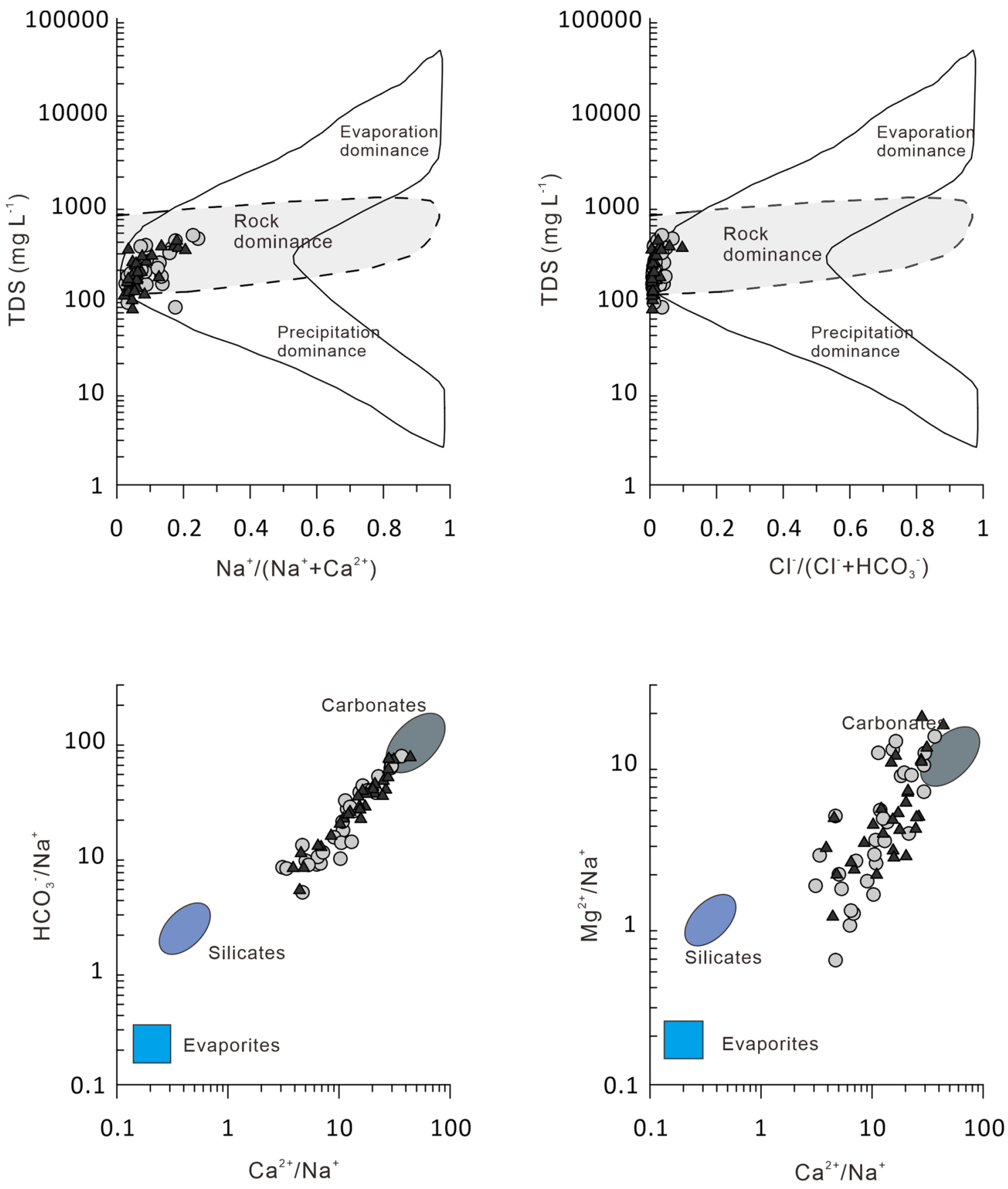

Figure 4. Gibbs (top) and mixing (bottom) diagrams for river water samples from the Chu-Talas river basin. The gray dots represent samples collected during low river flow and the black triangles represent samples collected during high river flow.

The evaluation of irrigation water noted above is based on the composition of major ions, but harmful effects on human health from potentially toxic elements in water are also of great concern. Research studies have shown that in developed countries and regions, potentially toxic elements have already had a significant impact on human health ${ }^{50,51}$. There is a particular gap in the study and evaluation of potentially toxic elements in the surface waters of Central Asia. Research on the arid regions of Central Asia is important for the future environmental protection and sustainable development of water resources. The daily average exposure doses from the ingestion and dermal absorption of potentially toxic elements in Chu-Talas river water were calculated, and the results of the human health risk assessment are presented in Table 2. With the calculation of the threshold value for the carcinogenic $(\mathrm{CI}=10-4)$ and non-carcinogenic risks $(\mathrm{HI}=1)$, the threshold values (non-carcinogenic) for $\mathrm{Pb}$, $\mathrm{Zn}, \mathrm{Cu}, \mathrm{Cr}$, and As were $124 \mu \mathrm{g} \mathrm{L}^{-1}, 10.8 \mathrm{mg} \mathrm{L}^{-1}, 1.44 \mathrm{mg} \mathrm{L}^{-1}, 61.5 \mathrm{ug} \mathrm{L}^{-1}$, and $484 \mu \mathrm{g} \mathrm{L}{ }^{-1}$, respectively. The carcinogenic threshold value for As was $2.41 \mu \mathrm{g} \mathrm{L}^{-1}$. And then, the margin of safety was derived from the difference between the threshold value for the carcinogenic and non-carcinogenic risks and the current value for potentially 


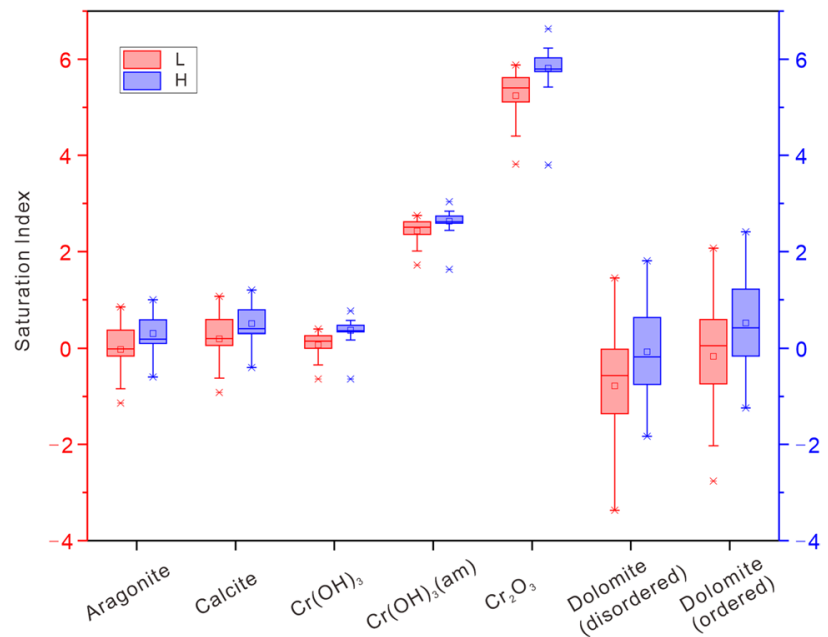

Figure 5. Saturation indices for the phases: Aragonite, Calcite, $\mathrm{Cr}(\mathrm{OH})_{3}, \mathrm{Cr}(\mathrm{OH})_{3}(\mathrm{am}), \mathrm{Cr}_{2} \mathrm{O}_{3}$, Dolomite (disordered), and Dolomite (ordered) at different periods: low river flow (L) and high river flow $(\mathrm{H})$.

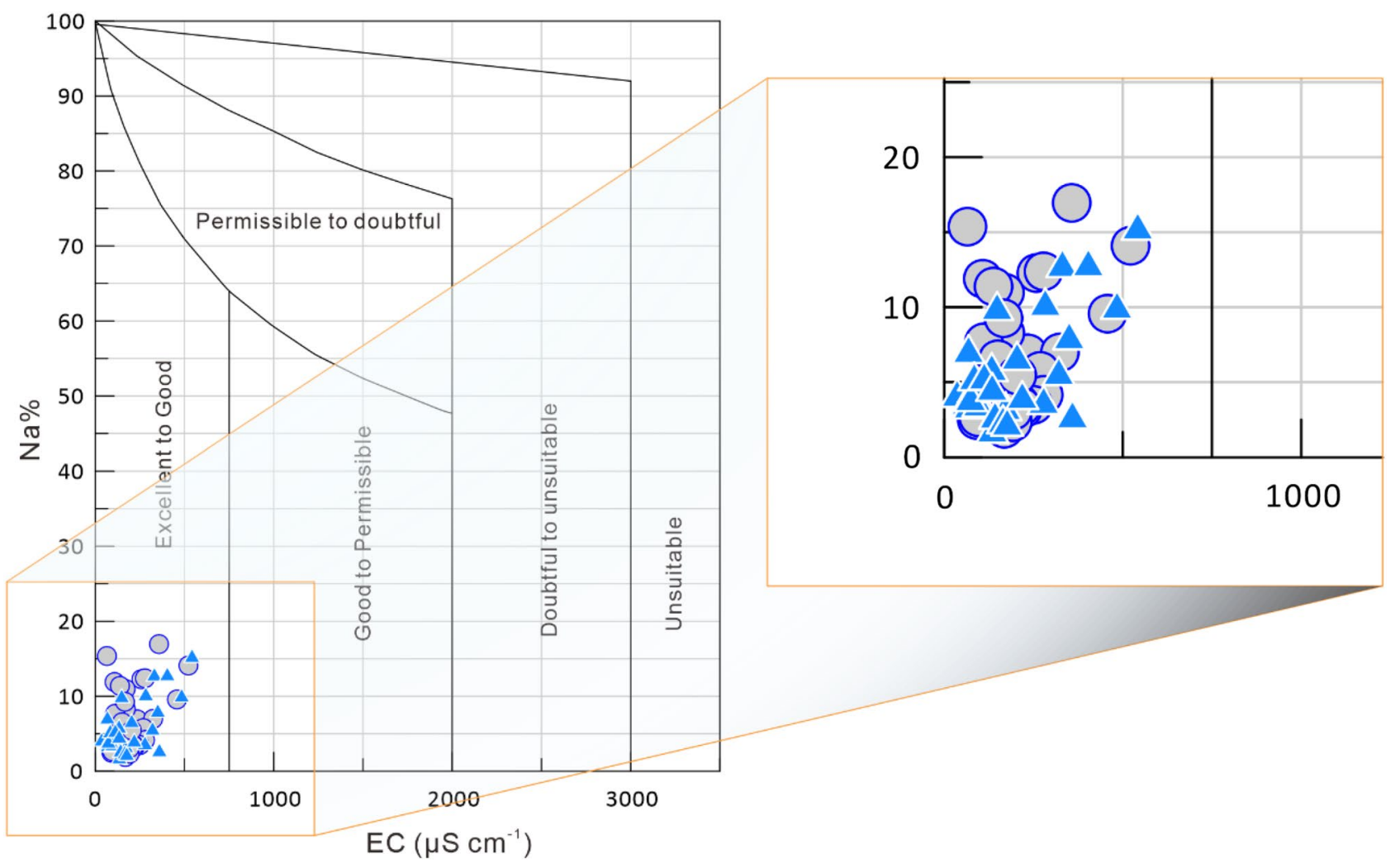

Figure 6. Wilcox diagram (\%Na vs. EC) for river water samples. The dots represent samples collected during low river flow and the triangles represent samples collected during high river flow.

toxic element in the study area. For non-carcinogenic risks, except for $\mathrm{Cr}$, the content of other elements is far below the risk threshold. However, during the low river flow stage, the $\mathrm{Cr}$ content of two sampling points was close to the risk threshold, resulting in $\mathrm{HI}$ close to $1(\mathrm{HI}=0.977)$. In the stage of high river flow, there is a point close to the risk threshold and a point above the risk threshold $(\mathrm{HI}=1.30)$. Based on the analysis presented in this study, the potentially toxic elements $\mathrm{Zn}, \mathrm{Pb}, \mathrm{Cu}$, and $\mathrm{As}$ may have been affected by human activities. However, according to the results of the human health risk assessment, both non-carcinogenic and carcinogenic risks are low. This might be because as a traditional agricultural and pastoral area, the Kyrgyz region has relatively low point source and non-point source pollution, and the level of pollution from human activities is very low. It should be noted that for both the dry season and the rainy season, the maximum carcinogenic risk index for As exceeded the allowable value and requires further consideration. Due to the carcinogenicity of the element As, 


\begin{tabular}{|c|c|c|c|c|c|c|}
\hline Stage & PTE & Minimum & Maximum & Mean & Median & Stage \\
\hline \multirow{18}{*}{$\mathrm{L}$} & \multirow{3}{*}{$\mathrm{Pb}$} & $\mathrm{HQ}_{\text {ing }}$ & $3.60 \mathrm{E}-04$ & $2.33 \mathrm{E}-02$ & $7.27 \mathrm{E}-03$ & $5.56 \mathrm{E}-03$ \\
\hline & & $\mathrm{HQ}_{\text {derm }}$ & $1.25 \mathrm{E}-05$ & $8.11 \mathrm{E}-04$ & $2.53 \mathrm{E}-04$ & $1.93 \mathrm{E}-04$ \\
\hline & & HI & $3.73 \mathrm{E}-04$ & $2.41 \mathrm{E}-02$ & $7.52 \mathrm{E}-03$ & $5.75 \mathrm{E}-03$ \\
\hline & \multirow{3}{*}{$\mathrm{Zn}$} & $\mathrm{HQ}_{\text {ing }}$ & $1.01 \mathrm{E}-04$ & $9.00 \mathrm{E}-04$ & $4.54 \mathrm{E}-04$ & $4.65 \mathrm{E}-04$ \\
\hline & & $\mathrm{HQ}_{\text {derm }}$ & $1.58 \mathrm{E}-06$ & $1.41 \mathrm{E}-05$ & $7.11 \mathrm{E}-06$ & $7.29 \mathrm{E}-06$ \\
\hline & & $\mathrm{HI}$ & $1.03 \mathrm{E}-04$ & $9.14 \mathrm{E}-04$ & $4.61 \mathrm{E}-04$ & $4.72 \mathrm{E}-04$ \\
\hline & \multirow{3}{*}{$\mathrm{Cu}$} & $\mathrm{HQ}_{\text {ing }}$ & $2.58 \mathrm{E}-04$ & $6.55 \mathrm{E}-03$ & $1.57 \mathrm{E}-03$ & $1.23 \mathrm{E}-03$ \\
\hline & & $\mathrm{HQ}_{\text {derm }}$ & $4.48 \mathrm{E}-06$ & $1.14 \mathrm{E}-04$ & $2.74 \mathrm{E}-05$ & $2.14 \mathrm{E}-05$ \\
\hline & & HI & $2.62 \mathrm{E}-04$ & $6.66 \mathrm{E}-03$ & $1.60 \mathrm{E}-03$ & $1.25 \mathrm{E}-03$ \\
\hline & \multirow{3}{*}{$\mathrm{Cr}$} & $\mathrm{HQ}_{\text {ing }}$ & $1.83 \mathrm{E}-01$ & $5.48 \mathrm{E}-01$ & $3.11 \mathrm{E}-01$ & $2.74 \mathrm{E}-01$ \\
\hline & & $\mathrm{HQ}_{\text {derm }}$ & $1.43 \mathrm{E}-01$ & $4.29 \mathrm{E}-01$ & $2.43 \mathrm{E}-01$ & $2.15 \mathrm{E}-01$ \\
\hline & & $\mathrm{HI}$ & $3.26 \mathrm{E}-01$ & $9.77 \mathrm{E}-01$ & $5.54 \mathrm{E}-01$ & $4.89 \mathrm{E}-01$ \\
\hline & \multirow{6}{*}{ As } & $\mathrm{HQ}_{\text {ing }}$ & $2.95 \mathrm{E}-04$ & $3.12 \mathrm{E}-03$ & $1.22 \mathrm{E}-03$ & $8.02 \mathrm{E}-04$ \\
\hline & & $\mathrm{HQ}_{\text {derm }}$ & $3.76 \mathrm{E}-04$ & $3.97 \mathrm{E}-03$ & $1.55 \mathrm{E}-03$ & $1.02 \mathrm{E}-03$ \\
\hline & & $\mathrm{HI}$ & $6.71 \mathrm{E}-04$ & $7.09 \mathrm{E}-03$ & $2.77 \mathrm{E}-03$ & $1.82 \mathrm{E}-03$ \\
\hline & & $\mathrm{CR}_{\text {ing }}$ & $1.33 \mathrm{E}-05$ & $1.40 \mathrm{E}-04$ & $5.49 \mathrm{E}-05$ & $3.61 \mathrm{E}-05$ \\
\hline & & $\mathrm{CR}_{\text {derm }}$ & $1.69 \mathrm{E}-07$ & $1.79 \mathrm{E}-06$ & $6.99 \mathrm{E}-07$ & $4.60 \mathrm{E}-07$ \\
\hline & & CI & $1.35 \mathrm{E}-05$ & $1.42 \mathrm{E}-04$ & $5.56 \mathrm{E}-05$ & $3.66 \mathrm{E}-05$ \\
\hline \multirow{18}{*}{$\mathrm{H}$} & \multirow{3}{*}{$\mathrm{Pb}$} & $\mathrm{HQ}_{\text {ing }}$ & $4.23 \mathrm{E}-04$ & $3.64 \mathrm{E}-02$ & $8.58 \mathrm{E}-03$ & $5.21 \mathrm{E}-03$ \\
\hline & & $\mathrm{HQ}_{\text {derm }}$ & $1.47 \mathrm{E}-05$ & $1.27 \mathrm{E}-03$ & $2.99 \mathrm{E}-04$ & $1.81 \mathrm{E}-04$ \\
\hline & & $\mathrm{HI}$ & $4.38 \mathrm{E}-04$ & $3.77 \mathrm{E}-02$ & $8.88 \mathrm{E}-03$ & $5.39 \mathrm{E}-03$ \\
\hline & \multirow{3}{*}{$\mathrm{Zn}$} & $\mathrm{HQ}_{\text {ing }}$ & $8.68 \mathrm{E}-05$ & $2.07 \mathrm{E}-03$ & $4.61 \mathrm{E}-04$ & $2.84 \mathrm{E}-04$ \\
\hline & & $\mathrm{HQ}_{\text {derm }}$ & $1.36 \mathrm{E}-06$ & $3.24 \mathrm{E}-05$ & $7.22 \mathrm{E}-06$ & $4.44 \mathrm{E}-06$ \\
\hline & & $\mathrm{HI}$ & $8.82 \mathrm{E}-05$ & $2.10 \mathrm{E}-03$ & $4.68 \mathrm{E}-04$ & $2.88 \mathrm{E}-04$ \\
\hline & \multirow{3}{*}{$\mathrm{Cu}$} & $\mathrm{HQ}_{\text {ing }}$ & $1.05 \mathrm{E}-04$ & $8.12 \mathrm{E}-03$ & $1.51 \mathrm{E}-03$ & $7.01 \mathrm{E}-04$ \\
\hline & & $\mathrm{HQ}_{\text {derm }}$ & $1.84 \mathrm{E}-06$ & $1.41 \mathrm{E}-04$ & $2.63 \mathrm{E}-05$ & $1.22 \mathrm{E}-05$ \\
\hline & & $\mathrm{HI}$ & $1.07 \mathrm{E}-04$ & $8.26 \mathrm{E}-03$ & $1.54 \mathrm{E}-03$ & $7.13 \mathrm{E}-04$ \\
\hline & \multirow{3}{*}{$\mathrm{Cr}$} & $\mathrm{HQ}_{\text {ing }}$ & $1.83 \mathrm{E}-01$ & $7.31 \mathrm{E}-01$ & $3.38 \mathrm{E}-01$ & $3.65 \mathrm{E}-01$ \\
\hline & & $\mathrm{HQ}_{\text {derm }}$ & $1.43 \mathrm{E}-01$ & $5.72 \mathrm{E}-01$ & $2.65 \mathrm{E}-01$ & $2.86 \mathrm{E}-01$ \\
\hline & & $\mathrm{HI}$ & $3.26 \mathrm{E}-01$ & $1.30 \mathrm{E}+00$ & $6.03 \mathrm{E}-01$ & $6.51 \mathrm{E}-01$ \\
\hline & \multirow{6}{*}{ As } & $\mathrm{HQ}_{\text {ing }}$ & $2.47 \mathrm{E}-04$ & $3.03 \mathrm{E}-03$ & $1.15 \mathrm{E}-03$ & $8.26 \mathrm{E}-04$ \\
\hline & & $\mathrm{HQ}_{\text {derm }}$ & $3.15 \mathrm{E}-04$ & $3.86 \mathrm{E}-03$ & $1.46 \mathrm{E}-03$ & $1.05 \mathrm{E}-03$ \\
\hline & & $\mathrm{HI}$ & $5.62 \mathrm{E}-04$ & $6.89 \mathrm{E}-03$ & $2.61 \mathrm{E}-03$ & $1.88 \mathrm{E}-03$ \\
\hline & & $\mathrm{CR}_{\text {ing }}$ & $1.11 \mathrm{E}-05$ & $1.36 \mathrm{E}-04$ & 5.17E-05 & $3.72 \mathrm{E}-05$ \\
\hline & & $\mathrm{CR}_{\text {derm }}$ & $1.42 \mathrm{E}-07$ & $1.74 \mathrm{E}-06$ & $6.58 \mathrm{E}-07$ & $4.73 \mathrm{E}-07$ \\
\hline & & CI & $1.12 \mathrm{E}-05$ & $1.38 \mathrm{E}-04$ & $5.24 \mathrm{E}-05$ & $3.77 \mathrm{E}-05$ \\
\hline
\end{tabular}

Table 2. Statistical summary of the human health risk assessment results for the ingestion of potentially toxic elements (PTE) in river waters of the Chu-Talas Basin during low river flow $(\mathrm{L})$ and high river flow $(\mathrm{H})$ periods.

during the low water flow, the As content of five sampling points out of 30 sampling points was higher than the carcinogenicity threshold. Correspondingly, during the high river flow, the As content of six sampling points was higher than the carcinogenicity threshold. Compared with the low river flow period, the increase in flow did not cause the concentration dilution effect to occur. On the contrary, the pollution degree of heavy metals increased to a certain extent, which may reflect the difference of the intensity of human social activities in different periods.

\section{Conclusions}

Based on the analysis of major ions and potentially toxic elements in river water of the Chu-Talas Basin, the factors affecting the main chemical composition were studied, and the irrigation suitability of river water and the human health risk of potentially toxic elements was evaluated. The main conclusions are as follows:

1. Although major ions in the river bodies of the basin are mainly affected by carbonate dissolution and silicate weathering, the sources of major ions change to some extent during different hydrological periods, but the hydrochemical type remains unchanged. Rivers in the basin are of the calcium carbonate hydrochemical type.

2. The relationship between the potentially toxic elements $\mathrm{Zn}, \mathrm{Pb}, \mathrm{Cu}, \mathrm{Cr}$, and $\mathrm{As}$ and major ions is basically the same under low and high river flow periods. There are significant differences in the sources of potentially 
toxic elements $(\mathrm{Zn}, \mathrm{Pb}, \mathrm{Cu}$, and $\mathrm{As})$ and major ions; however, the heavy metal $\mathrm{Cr}$ may share the same rock source as the major ions.

3. River water in the basin is classified as excellent/good for irrigation use based on the water quality assessment. According to the risk assessment, both non-carcinogenic and carcinogenic risks for human health are low. However, the maximum carcinogenic risk index for As exceeds the allowable during periods of both low and high river flow, which requires further consideration.

\section{Materials and methods}

Sampling and analysis. Sampling locations are shown in Fig. 7 and the geographic information for sampling points of surface rivers in Chu and Talas Basin during dry period with low river flow (May, 2017) and wet period with high river flow (July and August, 2017) were summarized in Table 3. Water samples from the Talas and Chu river basins were collected from 60 sites (Chu River sub-basin: $\mathrm{n}=18, \mathrm{C} 01-\mathrm{C} 18$; Talas River sub-basin: $\mathrm{n}=12$, T01-T12) during the low river flow period (May 2017) and again during the high river flow period (July and August 2017). In order to prevent contamination, river water samples were stored in clean 1.5-L polyethylene terephthalate bottles. Sub-samples were filtered through a $0.45-\mu \mathrm{m}$ filter and stored in a high-density polyethylene tube until the analysis. Prior to the analysis of cations and potentially toxic elements, water samples were acidified with $\mathrm{HNO}_{3}(65 \%)(\mathrm{pH}<2)$. During the collection of river water, the temperature, $\mathrm{pH}$, electrical conductivity (EC), and total dissolved solids (TDS) were measured in situ with an HI 9828 multi-parameter water quality meter (Hanna Instruments, Italy).

All of the laboratory analyses were performed at the Research Center for Ecology and Environment of Central Asia (Bishkek), Kyrgyzstan. The river water in the study area is weakly alkaline. According to the equilibrium relationship between the dissolved $\mathrm{CO}_{3}{ }^{2-}$ and $\mathrm{HCO}_{3}{ }^{-}$in water, the content of ion $\mathrm{CO}_{3}{ }^{2-}$ is very small, accounting for less than $5 \%$ of total. Therefore, the content of $\mathrm{CO}_{3}{ }^{2-}$ was ignored in this study. $\mathrm{HCO}_{3}{ }^{-}$was measured by potentiometric titration with a G20 compact titrator (Mettler Toledo AG, Switzerland). Cations $\mathrm{Ca}^{2+}, \mathrm{K}^{+}, \mathrm{Mg}^{2+}$, and $\mathrm{Na}^{+}$and anions $\mathrm{Cl}^{-}, \mathrm{NO}_{3}{ }^{-}$, and $\mathrm{SO}_{4}{ }^{2-}$ were determined using a Dionex ICS 900 ionic chromatography system (Thermo Fisher Scientific Inc., USA). The charge balance error percentage (CBE $)^{53,54}$ was less than $5 \%$. Potentially toxic elements $\mathrm{Zn}, \mathrm{Cu}, \mathrm{Pb}, \mathrm{Cr}$, and As were measured with an Agilent 8,800 inductively coupled plasma mass spectrometer (Agilent Technologies, USA).

Hydrochemical diagram and chemical speciation modeling. A Wilcox (1948) diagram with EC and sodium percentage $(\mathrm{Na} \%)^{49,55,56}$ was used for assessing the irrigation suitability of river waters. Piper diagrams ${ }^{57-59}$, Gibbs diagrams ${ }^{60-64}$, and mixing diagrams ${ }^{65-67}$ were used to determine influences of the river hydrochemistry. By using the software Phreeqc Interactive 3.6.2 with database file (minteq.v4.dat) ${ }^{68}$, chemical speciation modeling was conducted with major ions and the whole potentially toxic elements.

Human health risk assessment. For potentially toxic elements in aqueous systems, there are two common human exposure pathways: (a) direct ingestion and (b) dermal absorption ${ }^{69-71}$. The human health risks for non-carcinogenic and carcinogenic elements were calculated using Eqs. (1)-(8) below. Parameters used in the equations are defined in Table 4.

Daily exposure dose through oral intake $\left(\mathrm{ADD}_{\mathrm{ing}}\right)$ :

$$
A D D_{\text {ing }}=C_{h m} \times \frac{I n g R \times E F \times E D}{B W \times A T}
$$

Daily exposure dose through dermal contact $\left(\mathrm{ADD}_{\text {derm }}\right)$ :

$$
A D D_{\text {derm }}=C_{h m} \times \frac{S A \times K_{p} \times E T \times E F \times E D \times f_{1}}{B W \times A T}
$$

Hazard quotient for oral exposure $\left(\mathrm{HQ}_{\text {ing }}\right)$ :

$$
H Q_{\text {ing }}=A D D_{\text {ing }} / R f D_{\text {ing }}
$$

Hazard quotient for dermal exposure $\left(\mathrm{HQ}_{\mathrm{derm}}\right)$ :

$$
\mathrm{HQ}_{\text {derm }}=\mathrm{ADD}_{\text {derm }} / \mathrm{RfD}_{\text {derm }}
$$

Hazard index (HI):

$$
H I=H Q_{\text {ing }}+H Q_{\text {derm }}
$$

Carcinogenic risks for oral exposure $\left(\mathrm{CR}_{\text {ing }}\right)$ :

$$
C R_{\text {ing }}=A D D_{\text {ing }} \times C S F_{\text {ing }}
$$

Carcinogenic risks for dermal exposure $\left(\mathrm{CR}_{\mathrm{derm}}\right)$ :

$$
C R_{\text {derm }}=A D D_{\text {derm }} \times C S F_{\text {derm }}
$$

Total potential carcinogenic risks (CI):

$$
C I=C R_{\text {ing }}+C R_{\text {derm }}
$$



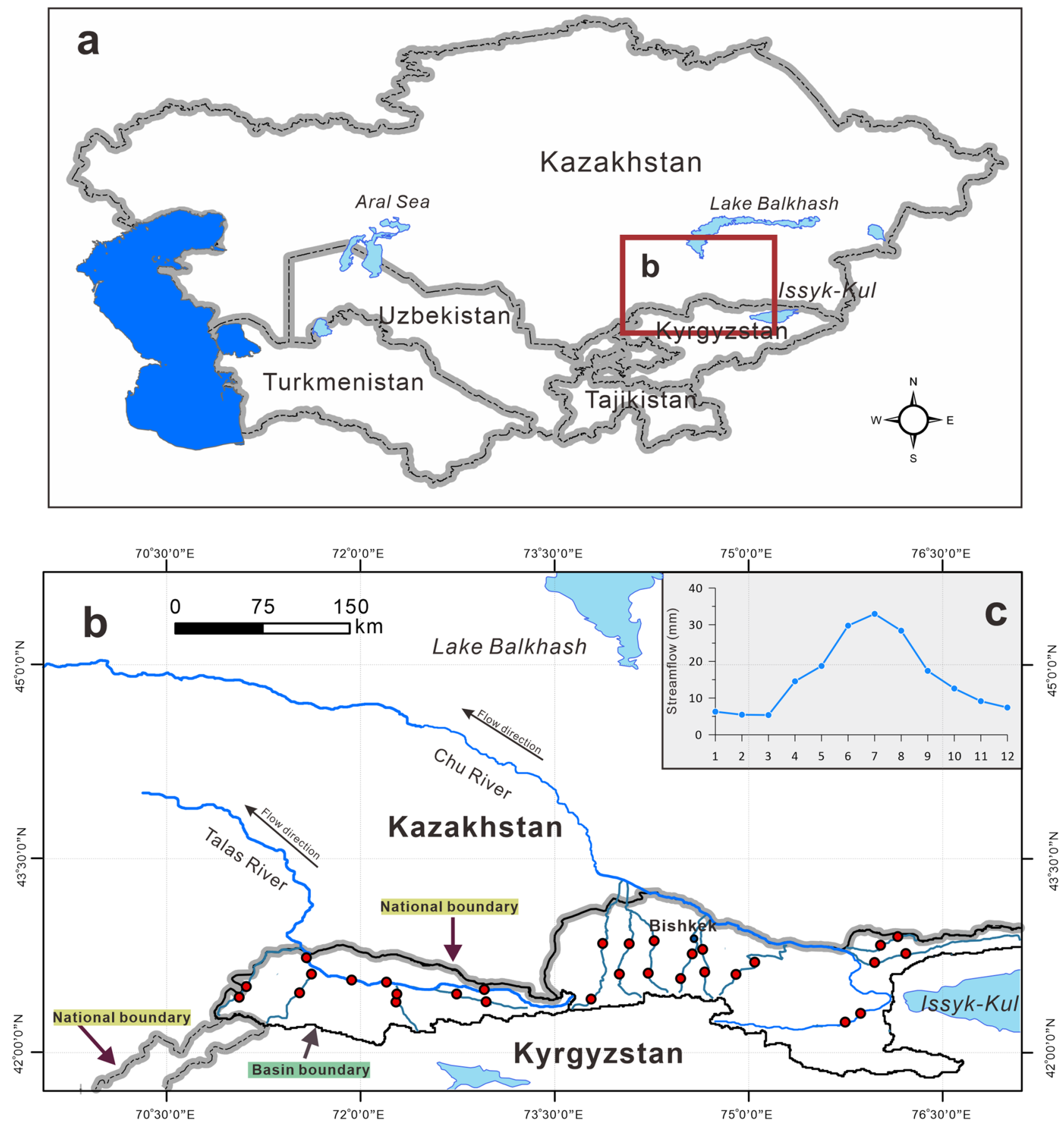

Figure 7. Geographical location map of the research area in Central Asia (a), the distribution of sampling site (b) with red dot, and the monthly distribution curve for the streamflow of River Chu (c). The diagrams of a and b were generated by QGIS 3.14 (https://www.qgis.org/) with the GADM Database of Global Administrative Areas (https://gadm.org), the Product of the Transboundary Freshwater Dispute Database (https://transbound arywaters.science.oregonstate.edu), and the Global Lakes and Wetlands Database (https://www.worldwildlife. org/pages/global-lakes-and-wetlands-database). The monthly distribution curve was generated by OriginPro 2020 (64-bit) SR1 9.7.0.188 (Learning Edition, https://www.originlab.com) with the data of streamflow of River Chu (1966-1955) ${ }^{52}$. The combination of three diagrams a, b, and c was conducted with the software Inkscape 1.0 (https://inkscape.org).

The values for Oral reference value $\left(\mathrm{RfD}_{\text {ing }}, \mathrm{mg} \mathrm{kg}^{-1}\right.$ day $\left.^{-1}\right)$, dermal reference value $\left(\mathrm{RfD}_{\text {derm }}\right)$, oral cancer slope factor $\left(\mathrm{CSF}_{\text {ing }},\left(\mathrm{mg} \mathrm{kg}^{-1} \mathrm{day}^{-1}\right)^{-1}\right)$ and dermal cancer slope factor $\left(\mathrm{CSF}_{\text {derm }}\right)$ were also shown in Table 4 . HI $<1$ or $\mathrm{HQ}<1$ : no non-carcinogenic risks; $\mathrm{HI}>1$ or $\mathrm{HQ}>1$ : there is potential risk for non-carcinogenic effects ${ }^{72}$; Acceptable or tolerable range of carcinogenic risks: $10^{-6}-10^{-473}$. 


\begin{tabular}{|c|c|c|c|c|c|c|c|c|}
\hline \multirow[b]{2}{*}{ Sampling sites } & \multirow[b]{2}{*}{ Elavation (m) } & \multirow[b]{2}{*}{ Latitude $\left({ }^{\circ} \mathrm{N}\right)$} & \multirow[b]{2}{*}{$\begin{array}{l}\text { Longitude } \\
\left({ }^{\circ} \mathrm{E}\right)\end{array}$} & \multirow[b]{2}{*}{ River name } & \multirow[b]{2}{*}{ River type } & \multicolumn{2}{|c|}{ Sampling date } & \multirow[b]{2}{*}{ Basin } \\
\hline & & & & & & $\begin{array}{l}\text { Low river } \\
\text { flow }\end{array}$ & $\begin{array}{l}\text { High river } \\
\text { flow }\end{array}$ & \\
\hline C01 & 1,370 & 42.601229 & 74.006862 & Ak-Suu $(\mathrm{Chu})$ & Tributary & $2017 / 5 / 5$ & $2017 / 7 / 25$ & Chu \\
\hline $\mathrm{C} 02$ & 734 & 42.836333 & 74.083778 & Ak-Suu (Chu) & Tributary & $2017 / 5 / 5$ & $2017 / 7 / 25$ & Chu \\
\hline $\mathrm{C} 03$ & 2,310 & 42.892347 & 76.157715 & Ak-Tuz & Tributary & $2017 / 5 / 27$ & $2017 / 7 / 26$ & Chu \\
\hline $\mathrm{C} 04$ & 1664 & 42.825144 & 76.024209 & Ak-Tuz & Tributary & $2017 / 5 / 27$ & $2017 / 7 / 26$ & Chu \\
\hline $\mathrm{C} 05$ & 1703 & 42.760964 & 76.22061 & Chon-Kemin & Tributary & $2017 / 5 / 25$ & $2017 / 7 / 27$ & Chu \\
\hline $\mathrm{C} 06$ & 1,401 & 42.691826 & 75.980247 & Chon-Kemin & Tributary & $2017 / 5 / 25$ & $2017 / 7 / 27$ & Chu \\
\hline $\mathrm{C} 07$ & 1802 & 42.226087 & 75.749446 & Kochkor & Main Stream & $2017 / 5 / 13$ & $2017 / 8 / 12$ & Chu \\
\hline $\mathrm{C} 08$ & 1,750 & 42.297176 & 75.872212 & Kochkor & Main Stream & $2017 / 5 / 13$ & $2017 / 8 / 12$ & Chu \\
\hline $\mathrm{C} 09$ & 1501 & 42.607957 & 74.229199 & Sokuluk & Tributary & $2017 / 5 / 5$ & $2017 / 8 / 15$ & Chu \\
\hline $\mathrm{C} 10$ & 719 & 42.859702 & 74.275902 & Sokuluk & Tributary & $2017 / 5 / 5$ & $2017 / 8 / 15$ & Chu \\
\hline C11 & 2,131 & 42.566487 & 74.4794752 & Ala-Archa & Tributary & $2017 / 5 / 6$ & $2017 / 8 / 15$ & Chu \\
\hline $\mathrm{C} 12$ & 1,077 & 42.758265 & 74.570389 & Ala-Archa & Tributary & $2017 / 5 / 6$ & $2017 / 8 / 15$ & Chu \\
\hline $\mathrm{C} 13$ & 1,490 & 42.618211 & 74.665793 & Alamedin & Tributary & $2017 / 5 / 7$ & $2017 / 8 / 16$ & Chu \\
\hline $\mathrm{C} 14$ & 1,008 & 42.791352 & 74.649447 & Alamedin & Tributary & $2017 / 5 / 7$ & $2017 / 8 / 16$ & Chu \\
\hline $\mathrm{C} 15$ & 1862 & 42.599819 & 74.907476 & Isik-Ata & Tributary & $2017 / 5 / 28$ & $2017 / 8 / 16$ & Chu \\
\hline $\mathrm{C} 16$ & 1,161 & 42.693147 & 75.052709 & Isik-Ata & Tributary & $2017 / 5 / 28$ & $2017 / 8 / 16$ & Chu \\
\hline $\mathrm{C} 17$ & 2070 & 42.40834 & 73.788627 & Kara-Balta & Tributary & $2017 / 5 / 29$ & $2017 / 7 / 24$ & Chu \\
\hline $\mathrm{C} 18$ & 742 & 42.839239 & 73.879112 & Kara-Balta & Tributary & $2017 / 5 / 29$ & $2017 / 7 / 24$ & Chu \\
\hline T01 & 1958 & 42.483125 & 72.963804 & Talas & Main Stream & $2017 / 5 / 27$ & $2017 / 7 / 25$ & Tals \\
\hline T02 & 1716 & 42.44727 & 72.749625 & Uch-Koshoi & Tributary & $2017 / 5 / 27$ & $2017 / 7 / 25$ & Tals \\
\hline T03 & 1,195 & 42.540373 & 72.206252 & Talas & Main Stream & $2017 / 5 / 25$ & $2017 / 7 / 26$ & Tals \\
\hline T04 & 1558 & 42.385749 & 72.28057 & Besh-Tash & Tributary & $2017 / 5 / 26$ & $2017 / 7 / 26$ & Tals \\
\hline T05 & 1,411 & 42.447463 & 72.286084 & Besh-Tash & Tributary & $2017 / 5 / 26$ & $2017 / 7 / 26$ & Tals \\
\hline T06 & 1,304 & 42.388164 & 72.977375 & Urmaral & Tributary & $2017 / 5 / 24$ & $2017 / 7 / 27$ & Tals \\
\hline T07 & 1,036 & 42.556107 & 71.938244 & Talas & Main Stream & $2017 / 5 / 24$ & $2017 / 7 / 27$ & Tals \\
\hline T08 & 1,247 & 42.45683 & 71.535456 & Kara-Buura & Tributary & $2017 / 5 / 23$ & $2017 / 7 / 28$ & Tals \\
\hline T09 & 928 & 42.601067 & 71.628187 & Kara-Buura & Tributary & $2017 / 5 / 23$ & $2017 / 7 / 28$ & Tals \\
\hline $\mathrm{T} 10$ & 772 & 42.728007 & 71.589141 & Talas & Main Stream & $2017 / 5 / 21$ & $2017 / 7 / 29$ & Tals \\
\hline T11 & 1637 & 42.422344 & 71.067557 & Kurkuroo & Tributary & $2017 / 5 / 22$ & $2017 / 7 / 30$ & Tals \\
\hline T12 & 1,215 & 42.505295 & 71.122779 & Kurkuroo & \begin{tabular}{|l|} 
Tributary \\
\end{tabular} & $2017 / 5 / 22$ & $2017 / 7 / 30$ & Tals \\
\hline
\end{tabular}

Table 3. The geographic information for sampling points of surface rivers in Chu and Talas Basin during dry period with low river flow and wet period with high river flow.

\begin{tabular}{|c|c|c|c|c|c|c|c|}
\hline Parameters & Meaning & Value & PTE & $\mathrm{RfD}_{\text {ing }}{ }^{74}$ & $\mathrm{RfD}_{\text {derm }}{ }^{74}$ & $\mathrm{CSF}_{\text {ing }}{ }^{74}$ & $\mathrm{CSF}_{\text {derm }}{ }^{74}$ \\
\hline $\mathrm{C}_{\mathrm{hm}}$ & $\begin{array}{l}\text { Concentration of potentially } \\
\text { toxic elements }\end{array}$ & $\mathrm{mg} \mathrm{L}^{-1}$ & $\mathrm{Zn}$ & $3.00 \mathrm{E}-01$ & $6.00 \mathrm{E}-02$ & - & - \\
\hline IngR & Ingestion rate & $2.0 \mathrm{~L} \mathrm{day}^{-175}$ & $\mathrm{Cu}$ & $4.00 \mathrm{E}-02$ & $1.20 \mathrm{E}-02$ & - & - \\
\hline $\mathrm{EF}$ & Exposure frequency & 350 day year ${ }^{-175}$ & $\mathrm{~Pb}$ & $3.50 \mathrm{E}-03$ & $5.25 \mathrm{E}-04$ & - & - \\
\hline $\mathrm{ED}$ & Exposure duration & 70 year $^{75}$ & $\mathrm{Cr}$ & $3.00 \mathrm{E}-03$ & $6.00 \mathrm{E}-05$ & - & - \\
\hline BW & Body weight & $70 \mathrm{~kg}^{76}$ & As & $3.00 \mathrm{E}-04$ & $1.23 \mathrm{E}-04$ & $1.50 \mathrm{E}+00$ & $3.66 \mathrm{E}+00$ \\
\hline AT & average life time & 25,550 days $^{75}$ & & & & & \\
\hline SA & $\begin{array}{l}\text { Drinking water exposed skin } \\
\text { area }\end{array}$ & $18,000 \mathrm{~cm}^{275}$ & & & & & \\
\hline $\mathrm{K}_{\mathrm{p}}$ & $\begin{array}{l}\text { Coefficient for dermal perme- } \\
\text { ability }\end{array}$ & $\begin{array}{l}0.001 \mathrm{~cm} \mathrm{~h}^{-175} ; \mathrm{Cr} 0.003^{75} ; \mathrm{Zn} \\
0.0006^{75}\end{array}$ & & & & & \\
\hline ET & exposure time & $0.58 \mathrm{~h} \mathrm{day}^{-175}$ & & & & & \\
\hline $\mathrm{F}_{1}$ & Factor for unit conversion & $\mathrm{L} 1,000 \mathrm{~cm}^{-177}$ & & & & & \\
\hline
\end{tabular}

Table 4. Definitions and values of parameters used in Eqs. (1)-(8) for human health risk calculations for Potentially toxic element (PTE). 
Received: 2 May 2020; Accepted: 24 August 2020

Published online: 11 September 2020

\section{References}

1. Guo, H. et al. Spatial and temporal characteristics of droughts in Central Asia during 1966-2015. Sci. Total Environ. 624, 1523-1538. https://doi.org/10.1016/j.scitotenv.2017.12.120 (2018).

2. Karthe, D., Chalov, S. \& Borchardt, D. Water resources and their management in central Asia in the early twenty first century: status, challenges and future prospects. Environ. Earth Sci. 73, 487-499. https://doi.org/10.1007/s12665-014-3789-1 (2015).

3. Hu, W., Liu, H., Bao, A. \& El-Tantawi, A. M. Influences of environmental changes on water storage variations in Central Asia. J. Geogr. Sci. 28, 985-1000. https://doi.org/10.1007/s11442-018-1517-6 (2018).

4. Crosa, G. et al. Spatial and seasonal variations in the water quality of the Amu Darya River (Central Asia). Water Res. 40, $2237-$ 2245. https://doi.org/10.1016/j.watres.2006.04.004 (2006).

5. Sorg, A., Bolch, T., Stoffel, M., Solomina, O. \& Beniston, M. Climate change impacts on glaciers and runoff in Tien Shan (Central Asia). Nat. Clim. Change 2, 725-731. https://doi.org/10.1038/nclimate1592 (2012).

6. Deng, H. \& Chen, Y. Influences of recent climate change and human activities on water storage variations in Central Asia. J. Hydrol. 544, 46-57. https://doi.org/10.1016/j.jhydrol.2016.11.006 (2017).

7. Kriegel, D. et al. Changes in glacierisation, climate and runoff in the second half of the 20th century in the Naryn basin, Central Asia. Glob. Planet. Change 110, 51-61. https://doi.org/10.1016/j.gloplacha.2013.05.014 (2013).

8. Micklin, P. The Aral Sea disaster. Annu. Rev. Earth Planet. Sci. 35, 47-72. https://doi.org/10.1146/annurev.earth.35.031306.14012 0 (2007).

9. Nezlin, N. P., Kostianoy, A. G. \& Lebedev, S. A. Interannual variations of the discharge of Amu Darya and Syr Darya estimated from global atmospheric precipitation. J. Mar. Syst. 47, 67-75. https://doi.org/10.1016/j.jmarsys.2003.12.009 (2004).

10. Ismaiylov, G. K., Fedorov, V. M. \& Sadati Nezhad, S. D. Assessment of possible anthropogenic changes in the runoff of the Syr Darya River on the basis of a mathematical model. Water Resour. 34, 359-371. https://doi.org/10.1134/S009780780704001X (2007).

11. Siegfried, T. et al. Will climate change exacerbate water stress in Central Asia?. Clim. Change 112,881-899. https://doi.org/10.1007/ s10584-011-0253-z (2012).

12. Savitskiy, A. G., Schlüter, M., Taryannikova, R. V., Agaltseva, N. A. \& Chub, V. E. Current and future impacts of climate change on river runoff in the Central Asian river basins. In Adaptive and Integrated Water Management: Coping with Complexity and Uncertainty (eds Pahl-Wostl, C. et al.) 323-339 (Springer, Berlin, 2008).

13. Bekturganov, Z. et al. Water related health problems in Central Asia-a review. Water 8, 219. https://doi.org/10.3390/w8060219 (2016)

14. Jensen, S., Mazhitova, Z. \& Zetterström, R. Environmental pollution and child health in the Aral Sea region in Kazakhstan. Sci. Total Environ. 206, 187-193. https://doi.org/10.1016/S0048-9697(97)80009-5 (1997).

15. Lind, O. et al. Environmental impact assessment of radionuclide and metal contamination at the former U site at Kadji Sai, Kyrgyzstan. J. Environ. Radioact. 123, 37-49. https://doi.org/10.1016/j.jenvrad.2012.07.010 (2013).

16. Imanberdieva, N., Chukunkyzy, N., Severoğlu, Z. \& Kulenbekov, Z. Ecology and environmental aspects of "Makmalzoloto" gold mining area in Kyrgyzstan. In Vegetation of Central Asia and Environs (eds Egamberdieva, D. et al.) 321-334 (Springer International Publishing, Cham, 2018)

17. Passell, H. D. et al. The Navruz Project: cooperative, transboundary monitoring, data sharing and modeling of water resources in Central Asia. In Nuclear Risks in Central Asia (eds Salbu, B. et al.) 191-199 (Springer, Amsterdam, 2008).

18. Barber, D. S. et al. The Navruz experiment: Cooperative monitoring for radionuclides and metals in Central Asia transboundary rivers. J. Radioanal. Nucl. Chem. 263, 213-218. https://doi.org/10.1007/s10967-005-0039-8 (2005).

19. Arsel, M. \& Spoor, M. Water, environmental security and sustainable rural development: conflict and cooperation in Central Eurasia. (Routledge, 2009).

20. Hartmann, J. \& Moosdorf, N. The new global lithological map database GLiM: A representation of rock properties at the Earth surface. Geochem. Geophys. Geosyst. 13, Q12004. https://doi.org/10.1029/2012GC004370 (2012).

21. FAO. Harmonized World Soil Database (version 1.2). FAO, Rome, Italy and IIASA, Laxenburg, Austria (2012).

22. Mamilov, N. S. Modern diversity of alien fish species in the Chu and Talas river basins. Russ. J. Biol. Invasions 2, 112. https://doi. org/10.1134/S207511171102007X (2011).

23. Xenarios, S., Shenhav, R., Abdullaev, I. \& Mastellari, A. Current and Future Challenges of Water Security in Central Asia (Global Water Security, New York, 2018).

24. Bernauer, T. \& Siegfried, T. Climate change and international water conflict in Central Asia. J. Peace Res. 49, 227-239. https://doi. org $110.1177 / 0022343311425843(2012)$

25. Zhiltsov, S. S., Zonn, I. S., Grishin, O. E., Egorov, V. G. \& Ruban, M. S. Transboundary rivers in Central Asia: cooperation and conflicts among countries. In Water Resources in Central Asia: International Context (eds Zhiltsov, S. S. et al.) 61-80 (Springer International Publishing, Cham, 2018).

26. Shil, S. \& Singh, U. K. Health risk assessment and spatial variations of dissolved heavy metals and metalloids in a tropical river basin system. Ecol. Indic. 106, 105455. https://doi.org/10.1016/j.ecolind.2019.105455 (2019).

27. Zhao, L. et al. Spatial-temporal distribution characteristics and health risk assessment of heavy metals in surface water of the Three Gorges Reservoir, China. Sci. Total Environ. 704, 134883. https://doi.org/10.1016/j.scitotenv.2019.134883 (2020).

28. Tabari, S., Saravi, S. S. S., Bandany, G. A., Dehghan, A. \& Shokrzadeh, M. Heavy metals (Zn, Pb, Cd and Cr) in fish, water and sediments sampled form Southern Caspian Sea, Iran. Toxicol. Ind. Health 26, 649-656. https://doi.org/10.1177/074823371037777 7 (2010).

29. Sodhi, K. K., Kumar, M., Agrawal, P. K. \& Singh, D. K. Perspectives on arsenic toxicity, carcinogenicity and its systemic remediation strategies. Environ. Technol. Innov. 16, 100462. https://doi.org/10.1016/j.eti.2019.100462 (2019).

30. Plum, L. M., Rink, L. \& Haase, H. The essential toxin: impact of zinc on human health. Int. J. Environ. Res. Public Health 7 , 1342-1365. https://doi.org/10.3390/ijerph7041342 (2010).

31. Khalid, M. \& Abdollahi, M. Epigenetic modifications associated with pathophysiological effects of lead exposure. J. Environ. Sci. Health Part C 37, 235-287. https://doi.org/10.1080/10590501.2019.1640581 (2019).

32. Alvarez-Ortega, N., Caballero-Gallardo, K. \& Olivero-Verbel, J. Toxicological effects in children exposed to lead: A cross-sectional study at the Colombian Caribbean coast. Environ. Int. 130, 104809. https://doi.org/10.1016/j.envint.2019.05.003 (2019).

33. Coetzee, J. J., Bansal, N. \& Chirwa, E. M. Chromium in environment, its toxic effect from chromite-mining and ferrochrome industries, and its possible bioremediation. Expo. Health 12, 51-62. https://doi.org/10.1007/s12403-018-0284-z (2020).

34. Rahman, Z. \& Singh, V. P. The relative impact of toxic heavy metals (THMs)(arsenic (As), cadmium (Cd), chromium (Cr)(VI), mercury $(\mathrm{Hg})$, and lead $(\mathrm{Pb})$ ) on the total environment: an overview. Environ. Monit. Assess. 191, 419. https://doi.org/10.1007/ s10661-019-7528-7 (2019).

35. Pacheco Castro, R., Pacheco Ávila, J., Ye, M. \& Cabrera Sansores, A. Groundwater quality: analysis of its temporal and spatial variability in a karst aquifer. Groundwater 56, 62-72. https://doi.org/10.1111/gwat.12546 (2018). 
36. Wei, H. et al. Revealing the correlations between heavy metals and water quality, with insight into the potential factors and variations through canonical correlation analysis in an upstream tributary. Ecol. Indic. 90, 485-493. https://doi.org/10.1016/j.ecoli nd.2018.03.037 (2018).

37. Wang, X., Zhao, L., Xu, H. \& Zhang, X. Spatial and seasonal characteristics of dissolved heavy metals in the surface seawater of the Yellow River Estuary, China. Mar. Pollut. Bull. 137, 465-473. https://doi.org/10.1016/j.marpolbul.2018.10.052 (2018).

38. Zhang, J., Hua, P. \& Krebs, P. Influences of land use and antecedent dry-weather period on pollution level and ecological risk of heavy metals in road-deposited sediment. Environ. Pollut. 228, 158-168. https://doi.org/10.1016/j.envpol.2017.05.029 (2017).

39. Hong, Z. et al. Evaluation of water quality and heavy metals in wetlands along the Yellow River in Henan Province. Sustainability 12, 1300. https://doi.org/10.3390/su12041300 (2020).

40. Sracek, O., Wanke, H., Ndakunda, N. N., Mihaljevič, M. \& Buzek, F. Geochemistry and fluoride levels of geothermal springs in Namibia. J. Geochem. Explor. 148, 96-104. https://doi.org/10.1016/j.gexplo.2014.08.012 (2015).

41. McPhillips, L. E., Creamer, A. E., Rahm, B. G. \& Walter, M. T. Assessing dissolved methane patterns in central New York groundwater. J. Hydrol. Reg. Stud. 1, 57-73. https://doi.org/10.1016/j.ejrh.2014.06.002 (2014).

42. Roques, C. et al. Autotrophic denitrification supported by biotite dissolution in crystalline aquifers: (2) transient mixing and denitrification dynamic during long-term pumping. Sci. Total Environ. 619-620, 491-503. https://doi.org/10.1016/j.scitotenv.2017.11.104 (2018).

43. Harris, I., Jones, P. D., Osborn, T. J. \& Lister, D. H. Updated high-resolution grids of monthly climatic observations-the CRU TS3.10 Dataset. Int. J. Climatol. 34, 623-642. https://doi.org/10.1002/joc.3711 (2014).

44. Xiao, J., Jin, Z., Wang, J. \& Zhang, F. Major ion chemistry, weathering process and water quality of natural waters in the Bosten Lake catchment in an extreme arid region, NW China. Environ. Earth Sci. 73, 3697-3708. https://doi.org/10.1007/s12665-014-3657-z (2015).

45. Hassen, I., Hamzaoui-Azaza, F. \& Bouhlila, R. Application of multivariate statistical analysis and hydrochemical and isotopic investigations for evaluation of groundwater quality and its suitability for drinking and agriculture purposes: case of Oum AliThelepte aquifer, central Tunisia. Environ. Monit. Assess. 188, 135. https://doi.org/10.1007/s10661-016-5124-7 (2016).

46. Adimalla, N. Groundwater quality for drinking and irrigation purposes and potential health risks assessment: a case study from semi-arid region of South India. Expo. Health 11, 109-123. https://doi.org/10.1007/s12403-018-0288-8 (2019).

47. Varol, S. \& Davraz, A. Evaluation of the groundwater quality with WQI (Water Quality Index) and multivariate analysis: a case study of the Tefenni plain (Burdur/Turkey). Environ. Earth Sci. 73, 1725-1744. https://doi.org/10.1007/s12665-014-3531-z (2015).

48. Ndoye, S., Fontaine, C., Gaye, B. C. \& Razack, M. Groundwater quality and suitability for different uses in the Saloum Area of Senegal. Water 10, 1837. https://doi.org/10.3390/w10121837 (2018).

49. Zhang, B. et al. Hydrochemical characteristics and water quality assessment of surface water and groundwater in Songnen plain, Northeast China. Water Res. 46, 2737-2748. https://doi.org/10.1016/j.watres.2012.02.033 (2012).

50. Kong, P., Cheng, X., Sun, R. \& Chen, L. The synergic characteristics of surface water pollution and sediment pollution with heavy metals in the Haihe River Basin, Northern China. Water 10, 73. https://doi.org/10.3390/w10010073 (2018).

51. Wang, Q. \& Yang, Z. Industrial water pollution, water environment treatment, and health risks in China. Environ. Pollut. 218, 358-365. https://doi.org/10.1016/j.envpol.2016.07.011 (2016).

52. Ma, C., Sun, L., Liu, S., Shao, M. A. \& Luo, Y. Impact of climate change on the streamflow in the glacierized Chu River Basin, Central Asia. J. Arid Land 7, 501-513. https://doi.org/10.1007/s40333-015-0041-0 (2015).

53. Talib, A. M. et al. Hydrogeochemical characterization and suitability assessment of groundwater: a case study in Central Sindh, Pakistan. Int. J. Environ. Res. Public Health 16, 886. https://doi.org/10.3390/ijerph16050886 (2019).

54. Rotiroti, M. et al. The effects of irrigation on groundwater quality and quantity in a human-modified hydro-system: the Oglio River basin, Po Plain, northern Italy. Sci. Total Environ. 672, 342-356. https://doi.org/10.1016/j.scitotenv.2019.03.427 (2019).

55. Nazzal, Y. et al. A pragmatic approach to study the groundwater quality suitability for domestic and agricultural usage, Saq aquifer, northwest of Saudi Arabia. Environ. Monit. Assess. 186, 4655-4667. https://doi.org/10.1007/s10661-014-3728-3 (2014).

56. Subramani, T., Elango, L. \& Damodarasamy, S. R. Groundwater quality and its suitability for drinking and agricultural use in Chithar River Basin, Tamil Nadu, India. Environ. Geol. 47, 1099-1110. https://doi.org/10.1007/s00254-005-1243-0 (2005).

57. Zhang, Y. et al. Hydrochemical characteristics and multivariate statistical analysis of natural water system: a case study in Kangding County, Southwestern China. Water 10, 80. https://doi.org/10.3390/w10010080 (2018).

58. Rehman Qaisar, F. U. et al. Spatial variation, source identification, and quality assessment of surface water geochemical composition in the Indus River Basin, Pakistan. Environ. Sci. Pollut. Res. 25, 12749-12763. https://doi.org/10.1007/s11356-018-1519-z (2018).

59. Wang, Z., Guo, H., Xiu, W., Wang, J. \& Shen, M. High arsenic groundwater in the Guide basin, northwestern China: distribution and genesis mechanisms. Sci. Total Environ. 640-641, 194-206. https://doi.org/10.1016/j.scitotenv.2018.05.255 (2018).

60. Zhang, T., Pu, J., Li, J., Yuan, D. \& Li, L. Stable isotope and aquatic geochemistry of a typical subtropical karst subterranean stream in southwest China. Carbonates Evaporites 32, 415-430. https://doi.org/10.1007/s13146-017-0356-3 (2017).

61. Weynell, M., Wiechert, U. \& Zhang, C. Chemical and isotopic (O, H, C) composition of surface waters in the catchment of Lake Donggi Cona (NW China) and implications for paleoenvironmental reconstructions. Chem. Geol. 435, 92-107. https://doi. org/10.1016/j.chemgeo.2016.04.012 (2016).

62. Dehbandi, R., Moore, F. \& Keshavarzi, B. Geochemical sources, hydrogeochemical behavior, and health risk assessment of fluoride in an endemic fluorosis area, central Iran. Chemosphere 193, 763-776. https://doi.org/10.1016/j.chemosphere.2017.11.021 (2018).

63. Li, C., Gao, X. \& Wang, Y. Hydrogeochemistry of high-fluoride groundwater at Yuncheng Basin, northern China. Sci. Total Environ. 508, 155-165. https://doi.org/10.1016/j.scitotenv.2014.11.045 (2015).

64. Rashid, A. et al. Fluoride prevalence in groundwater around a fluorite mining area in the flood plain of the River Swat, Pakistan. Sci. Total Environ. 635, 203-215. https://doi.org/10.1016/j.scitotenv.2018.04.064 (2018).

65. Li, S. et al. Chemical balance of the Yellow River source region, the northeastern Qinghai-Tibetan Plateau: Insights about critical zone reactivity. Appl. Geochem. 90, 1-12. https://doi.org/10.1016/j.apgeochem.2017.12.016 (2018)

66. Meyer, K. J., Carey, A. E. \& You, C. F. Typhoon impacts on chemical weathering source provenance of a High Standing Island watershed, Taiwan. Geochim. Cosmochim. Acta 215, 404-420. https://doi.org/10.1016/j.gca.2017.07.015 (2017).

67. Qu, B., Zhang, Y., Kang, S. \& Sillanpää, M. Water quality in the Tibetan Plateau: major ions and trace elements in rivers of the "Water Tower of Asia". Sci. Total Environ. 649, 571-581. https://doi.org/10.1016/j.scitotenv.2018.08.316 (2019).

68. Parkhurst, D. L. \& Appelo, C. Description of input and examples for PHREEQC version 3: a computer program for speciation, batch-reaction, one-dimensional transport, and inverse geochemical calculations. Report no. 2328-7055 (US Geological Survey, 2013).

69. Singh, U. K., Ramanathan, A. L. \& Subramanian, V. Groundwater chemistry and human health risk assessment in the mining region of East Singhbhum, Jharkhand, India. Chemosphere 204, 501-513. https://doi.org/10.1016/j.chemosphere.2018.04.060 (2018).

70. Wang, J., Liu, G., Liu, H. \& Lam, P. K. S. Multivariate statistical evaluation of dissolved trace elements and a water quality assessment in the middle reaches of Huaihe River, Anhui, China. Sci. Total Environ. 583, 421-431. https://doi.org/10.1016/j.scito tenv.2017.01.088 (2017).

71. Ma, Y., Egodawatta, P., McGree, J., Liu, A. \& Goonetilleke, A. Human health risk assessment of heavy metals in urban stormwater. Sci. Total Environ. 557-558, 764-772. https://doi.org/10.1016/j.scitotenv.2016.03.067 (2016).

72. Ma, L., Abuduwaili, J., Li, Y. \& Liu, W. Anthropogenically disturbed potentially toxic elements in roadside topsoils of a suburban region of Bishkek, Central Asia. Soil Use Manag. 35, 283-292. https://doi.org/10.1111/sum.12470 (2019). 
73. $\mathrm{Hu}, \mathrm{X}$. et al. Bioaccessibility and health risk of arsenic and heavy metals (Cd Co, Cr, Cu, Ni, Pb, Zn and Mn) in TSP and PM2.5 in Nanjing, China. Atmos. Environ. 57, 146-152. https://doi.org/10.1016/j.atmosenv.2012.04.056 (2012).

74. De Miguel, E., Iribarren, I., Chacón, E., Ordoñez, A. \& Charlesworth, S. Risk-based evaluation of the exposure of children to trace elements in playgrounds in Madrid (Spain). Chemosphere 66, 505-513. https://doi.org/10.1016/j.chemosphere.2006.05.065 (2007).

75. Xiao, J., Wang, L., Deng, L. \& Jin, Z. Characteristics, sources, water quality and health risk assessment of trace elements in river water and well water in the Chinese Loess Plateau. Sci. Total Environ. 650, 2004-2012. https://doi.org/10.1016/j.scito tenv.2018.09.322 (2019).

76. Liang, B. et al. Distribution, sources, and water quality assessment of dissolved heavy metals in the Jiulongjiang River Water, Southeast China. Int. J. Environ. Res. Public Health 15, 2752. https://doi.org/10.3390/ijerph15122752 (2018).

77. Liu, X. et al. Human health risk assessment of heavy metals in soil-vegetable system: a multi-medium analysis. Sci. Total Environ. 463-464, 530-540. https://doi.org/10.1016/j.scitotenv.2013.06.064 (2013).

\section{Acknowledgements}

This research is funded by the Strategic Priority Research Program of Chinese Academy of Sciences (XDA20060303), the National Natural Science Foundation of China (U1903115), Tianshan Youth Program of Xinjiang Uygur Autonomous Region, China (2018Q008), and the High-level Training Project of Xinjiang Institute of Ecology and Geography, CAS (E050030101).

\section{Author contributions}

Study design: L.M, Y.L. Analysis and interpretation of data: J.A., W.L., S.A. Drafting and revising the manuscript: L.M, J.A., Y.L. All authors read and approved the final version of the manuscript.

\section{Competing interests}

The authors declare no competing interests.

\section{Additional information}

Supplementary information is available for this paper at https://doi.org/10.1038/s41598-020-71880-4.

Correspondence and requests for materials should be addressed to L.M.

Reprints and permissions information is available at www.nature.com/reprints.

Publisher's note Springer Nature remains neutral with regard to jurisdictional claims in published maps and institutional affiliations.

(c) Open Access This article is licensed under a Creative Commons Attribution 4.0 International License, which permits use, sharing, adaptation, distribution and reproduction in any medium or format, as long as you give appropriate credit to the original author(s) and the source, provide a link to the Creative Commons licence, and indicate if changes were made. The images or other third party material in this article are included in the article's Creative Commons licence, unless indicated otherwise in a credit line to the material. If material is not included in the article's Creative Commons licence and your intended use is not permitted by statutory regulation or exceeds the permitted use, you will need to obtain permission directly from the copyright holder. To view a copy of this licence, visit http://creativecommons.org/licenses/by/4.0/.

(C) The Author(s) 2020 